Canadian

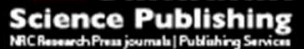

Canadian Journal of Civil Engineering Revue canadienne de génie civil

\title{
Clear-water scour evolution at dual bridge piers
}

\begin{tabular}{|r|l|}
\hline Journal: & Canadian Journal of Civil Engineering \\
\hline Manuscript ID & cjce-2016-0053.R2 \\
\hline Manuscript Type: & Article \\
\hline Date Submitted by the Author: & $29-$ Sep-2016 \\
\hline Complete List of Authors: & $\begin{array}{l}\text { Yilmaz, Meric; Orta Dogu Teknik Universitesi, Civil Engineering } \\
\text { Yanmaz, Melih; Orta Dogu Teknik Universitesi, } \\
\text { Koken, Mete; Orta Dogu Teknik Universitesi, Civil Engineering }\end{array}$ \\
\hline Keyword: & bridge, pier group, clear-water scour, sediment pickup \\
\hline
\end{tabular}

SCHOLARONE $^{\mathrm{m}}$

Manuscripts 
Title:

Clear-water scour evolution at dual bridge piers

Authors:

Meric Yilmaz

Melih Yanmaz

Mete Koken

\section{Addresses:}

M. Yilmaz. Department of Civil Engineering, Orta Dogu Teknik Universitesi, 06800, Ankara, Turkey

M. Yanmaz. Department of Civil Engineering, Orta Dogu Teknik Universitesi, 06800, Ankara, Turkey

M. Koken. Department of Civil Engineering, Orta Dogu Teknik Universitesi, 06800, Ankara, Turkey

Corresponding author:

Meric Yilmaz (e-mail: smeric@metu.edu.tr) 
Abstract: For the efficient design of bridge pier footings, computation of time-evolution of scour depth around bridge piers is essential. In this paper, a semi-empirical model is developed to estimate the temporal variation of clear-water scour depth at couple of identical cylindrical uniform piers in tandem arrangement. The experiments are carried out using different pier size, pier spacing, and flow intensities. The model development is based on sediment continuity approach and volumetric sediment transport rate from the scour hole using a sediment pickup function. The model results are presented as design charts giving the relation between dimensionless scour depth and time for practical use. Results of the proposed model are in relatively good agreement with the experimental results, in the test range.

Key words: Bridge, pier group, clear-water scour, sediment pickup

Résumé: Pour une conception efficace de la fondation des piles de pont, il est important de déterminer l'évolution temporelle de la profondeur des affouillements autour de ces piles. Dans cet article, un modèle semi-empirique est développé pour estimer la variation temporelle de la profondeur d'affouillement en eau claire à une paire de piles identiques, de forme cylindrique et uniforme, de disposition en tandem. Des expériences ont été menées pour des différentes valeurs de tailles de piles, d'espacement entre les piles et d'intensités de flux. Le développement du modèle est basé sur l'approche de continuité des sédiments et sur le taux de transport de dépôt volumétrique de la fosse d'affouillement, en utilisant une fonction de soulèvement des sédiments. Pour la praticité d'utilisation, les résultats du modèle sont présentés sous forme d'abaque de conception donnant la relation entre la profondeur adimensionnelle d'affouillements et le temps. Les résultats proposés par le modèle sont relativement en bon accord avec les résultats expérimentaux dans la plage d'essai.

Mots-clés: Pont, groupe de pile, eau claire affouillement, soulèvement des sédiments 


\section{Introduction}

Determination of local scour depth around bridge foundations has received significant attention since the mid of the $20^{\text {th }}$ century. Apart from the studies on abutment scour, most of the previous studies have been concentrated on the determination of equilibrium scour depth around single piers. Due to complexity of the nature of scouring process, many empirical equations have been derived to obtain the equilibrium depth of scour for specified range of experimental conditions, such as pier size, flow characteristics, and sediment properties. An evaluation on the most recent and commonly used equilibrium scour prediction equations have been carried out by Sheppard et al. (2014) and a design method has been proposed eventually. In clear-water scour case, the equilibrium scour depth is attained asymptotically with time and it takes several days in laboratory medium to reach the equilibrium condition (Breusers et al. 1977; Melville and Chiew 1999). Several criteria were proposed for the time to reach the equilibrium scour depth (Franzetti et al. 1994; Cardoso and Bettess 1999; Melville and Chiew 1999; Coleman et al. 2003; SimarroGrande and Martin-Vide 2004). Generally in an experimental duration of 24 hours, the equilibrium scour condition is accepted to be attained when the increase in the scour depth is below a limiting value. This increase was proposed to be less than $5 \%$ of the pier diameter by Melville and Chiew (1999), $1.7 \%$ of the pier diameter by Grimaldi et al. (2006), and twice the median sediment size by Fael et al. (2006). In another study, Setia (2008) stated that in laboratory conditions, even a duration of 100 hours is not long enough to reach equilibrium condition. Lança et al. (2010) assessed subjectivity of the aforementioned criterion and highlighted deficiency in reaching exact equilibrium. However, in field, peak value of the design hydrograph may not last long as the time to attain equilibrium condition (Mia and Nago 2003). Design of piers and countermeasures on the basis of equilibrium condition give conservative results and hence leading to uneconomical design (Yanmaz and Altinbilek 1991). Therefore, investigation of time-dependent evolution of scour depth provides realistic mean for hydraulic design. 
Pioneering studies have been conducted by Chabert and Engeldinger (1956) and Ettema (1980) on the temporal variation of scour depth at single bridge piers. Melville and Chiew (1999) developed a method for the time evolution of pier scour using the experimental data of Ettema (1980) and new experiments. Kothyari et al. (1992) and Kothyari and Kumar (2012) studied the time-dependent clear-water scour depth at circular uniform and circular compound piers, respectively. They also introduced the time variation of shear stresses inside the scour hole in their study. Yanmaz and Altinbilek (1991) developed a semi-empirical model to estimate the clear-water scour depth at single cylindrical and square piers. Their model was updated by Yanmaz (2006) for cylindrical piers. Further semi-empirical models were proposed by Mia and Nago (2003) and Lu et al. (2011) to determine the temporal variation of scour depth at circular uniform and circular compound piers, respectively. In all semi-empirical studies mentioned above, the volume of the scour hole was approximated by the volume of an inverted conical frustum. In another semiempirical model proposed by Guo (2014), volume of scour hole expression was slightly different than this definition. The temporal evolution of scour at piers has been further studied by Kothyari and Ranga Raju (2001), Oliveto and Hager (2002), Chang et al. (2004), Sheppard et al. (2004), and Oliveto and Hager (2005).

For geotechnical and structural purposes, design of a bridge foundation may include group of piers. However, further complexity of the scour mechanism due to sediment-laden flow interaction between neighboring piers makes prediction of the local scour depth relatively difficult compared to the case of a single pier (Ataie-Ashtiani and Beheshti 2006). In addition to the scour mechanism at single piers with major driving flows, namely downflow, horse-shoe vortex, and wake vortex, there are other mechanisms in case of pier groups. In tandem arrangement, where couple of piers are placed at the centerline aligned with the flow, these mechanisms are reinforcing, sheltering, and vortex shedding (Hannah 1978). Effective mechanism on the scour depth at the upstream of the front pier is reinforcing. In this mechanism, the scour depth at the front pier increases by 
overlapping of the scour holes around front and rear piers. The intensity of reinforcing decreases with increasing pier spacing (Hosseini and Amini 2015). Studies on pier groups are mostly concentrated on the determination of equilibrium scour depth and effect of spacing between piers. Hannah (1978) carried out a detailed study for different arrangements of pier groups and spacing between piers. Hannah (1978) concluded that the equilibrium scour depth at the front pier reaches its maximum value when $\lambda \approx 0.40$, where $\lambda$ is the ratio of pier diameter $(b)$ to center-to-center spacing between piers $(d)$. As $\lambda$ decreases, the interference of scour holes decreases and in the test range of experiments conducted by Hannah (1978) when $\lambda<0.09$, the scour holes around front and rear piers act as separate holes (Yanmaz, 2002). Basak et al. (1978) studied the maximum scour depth at cylindrical pier groups with reference to the effect of pier spacing and angle of attacking flow. The effect of pier spacing on the equilibrium scour depth at pier groups has received attention by several researchers (Elliott and Baker 1985; Salim and Jones 1998; Ataie-Ashtiani and Beheshti 2006; Heidarpour et al. 2010; Gao et al. 2013; Beg and Beg 2015). The scour depth reaches its maximum value when $\lambda \approx 0.33$ in Ataie-Ashtiani and Beheshti (2006) and Beg (2004) while the scour depths are very close when $\lambda=0.50$ and $\lambda=0.33$. In addition to those experimental studies, the numerical investigation of local scour at group of piers was carried out by Kim et al. (2014). In their study, the maximum value of equilibrium scour depth is obtained when $\lambda \approx 0.40$. Together with the effect of pier spacing on the equilibrium scour depth, they have investigated the time-evolution of the scour depth. All researchers observed that, the equilibrium scour depth increases with decreasing $\lambda$ and reach its maximum value at $\lambda=0.33-0.40$, and then it decreases.

The aim of this study is to develop a semi-empirical model for the temporal variation of clearwater scour depth in the combined scour hole of dual cylindrical uniform piers in tandem arrangement. The model is developed for the spatial instantaneous maximum scour depth in the combined scour hole, which always occurs at the upstream of the front pier. The model is based on the application of sediment continuity approach and volumetric sediment transport rate from the 
scour hole. With the aid of experimental data, time-evolution of the volume of the scour hole around the dual piers was obtained and the sediment transport rate out of the scour hole was formulated using a sediment pickup function. The experimental results were coupled in sediment continuity equation of the scour hole to obtain temporal variation of the depth of scour around the front pier. Therefore, the developed model turned out to have a semi-empirical nature. The effect of spacing between the piers was included in the model in a range that scour holes around front and rear piers are overlapping. The flow structures developing around tandem bridge piers which are clearly explained by Hannah (1978) are also observed in the course of the experimental process.

\section{Experimental setup and procedure}

\subsection{General}

The experiments were conducted in a 15.2-m-long, 0.72-m-wide, and 1.0-m-deep rectangular flume in the Hydromechanics Laboratory of Civil Engineering Department, Orta Dogu Teknik Universitesi, Ankara, Turkey. Plan view of the test flume is shown in Fig. 1. As can be seen from Fig. 1, a 4.5-m-long working section was located $5.6 \mathrm{~m}$ downstream of the flume inlet. The working section was filled with uniform bed material as a $0.3-\mathrm{m}$-thick layer and the rest of the flume bottom was made of varnished concrete. Quartz sand having a median size $\left(D_{50}\right)$ of $0.88 \mathrm{~mm}$ was used as bed material and its geometric standard deviation $\left(\sigma_{g}\right)$ was 1.284 so that the material was considered uniform (Dey et al. 1995; Melville and Coleman 2000). In the first 1.6-m-long part of the flume, steel meshes were installed to reduce turbulence in the inflow. To enable a gradual transition from concrete bed to sediment, pebbles were placed at the upstream of the working section. The bed slope $\left(S_{0}\right)$ of the concrete section was 0.001 and the sediment-filled section was flattened accordingly to maintain a constant bed slope along the flume. In the experiments, couple of identical pier models was placed at the centerline of the sediment section aligned with the flow direction. The PVC pier models were cylindrical and had three different diameters $(b)$ of 7.5, 6.3, 
and $4.0 \mathrm{~cm}$. The front piers were located approximately $7.85 \mathrm{~m}$ downstream of the flume inlet. Three different pier spacing $(d)$, were tested with $d=2 b, 3 b$, and $4 b$. During the experiments, clearwater scour conditions were maintained, i.e. the shear velocities in the approach flow $\left(u_{*}\right)$ were less than the critical shear velocity of the sediment $\left(u_{* c}\right)$ according to Shields' criterion (Garde and Ranga Raju 2006). Using a flow meter installed on the inflow pipe, the inflow rate was adjusted. An outflow pipe was installed at the downstream of the test flume to discharge the flow to a secondary channel. A sharp crested weir in the secondary channel was used to check the inflow rate by reading the head on the weir.

The scope of the experiments is presented in Table 1. Series of experiments were conducted in two parts. In the first part of the experiments (E2-E7), temporal variation of the scour hole topography was obtained around dual piers. The volume of the common scour hole was determined as a function of $\lambda, b$, time $(t)$, and depth of scour $\left(d_{s}\right)$. The second part of the experiments (E11-E17) was conducted to obtain the temporal evolution of scour depth at the upstream of the front pier. Together with the volume expression determined in the first part of the experiments, the findings of the second part were used to develop a semi-empirical model for determining the temporal variation of clear-water scour depth at the upstream face of the front pier. In Table $1, d_{0}$ is the approach flow depth, $Q$ is the discharge, $u$ is the mean approach flow velocity, $u_{c}$ is the mean threshold velocity in the approach flow, $F_{d}=u /\left(\Delta g D_{50}\right)^{0.5}$ is the densimetric particle Froude number, $\Delta=\rho_{s} / \rho-1$ is the relative submerged density, $\rho_{s}$ is the sediment density, $\rho$ is the water density, and $g$ is the gravitational acceleration.

As mentioned earlier, very long test duration is required to reach the equilibrium scour depth under clear-water conditions. Regarding the aim to investigate the time evolution of scour hole characteristics, it was intended to study the initial and development phases of scouring. At the end of these first two rapid evolution phases among four phases of scouring, $85-95 \%$ of the equilibrium scour depth is reached (Zanke 1978; Hoffmans and Verheij 1997; Link 2006). Also, according to 
Melville and Chiew (1999), depending on the approach flow velocity, after $10 \%$ of the time to equilibrium, the scour depth around single cylindrical pier is about $50-80 \%$ of the equilibrium scour depth. In the light of these studies on the evolution of scour process, the maximum test duration in both parts of the experiments was specified as 6 hours, which corresponds to initial and development phases of scouring. The test duration also corresponds to relatively long flow durations in the prototype. For example, for a 1:50 scaled Froude modeling, this duration corresponds to $6^{*}(50)^{0.5}=42$ hours in prototype conditions. This may be a reasonable time to peak value for most common storms composed of single peaks. Furthermore, as stated before, peak value of the design hydrograph is normally not last long as the time to attain the equilibrium scour depth.

\subsection{Experiments on temporal variation of scour hole topography}

In this part of the experimental study, the aim was to obtain three-dimensional map of the scour hole bathymetry around tandem piers and to determine the temporal variation of the scour hole characteristics. Considering similarity of the scour hole characteristics under different flow intensities in the range of clear water conditions, the experiments were conducted with a constant flow intensity of $u / u_{c}=0.946$, which is close to the upper limit of clear-water conditions. We observed minor transport of sediment particles in the upstream bed; however this weak motion was not observed to alter the bed topography significantly. Each experiment was started with a flattened bed. While the outlet valve was closed, the flume was filled with water very slowly without disturbing the bed material, until desired flow depth was reached. Then the inflow valve was adjusted to the desired discharge in the flume and outlet valve was fully opened. To obtain timedependent three-dimensional map of the scour hole, each experiment was stopped at different times. In experiments E4-E7, the mapping times were 5, 20, 60, 100, 150, and 360 minutes. However, in experiments E2-E3, larger scour hole volume and scour surface area were expected due to use of larger pier diameter, therefore more frequent mapping times were considered, such as 5, 10, 15, 20, 
$30,45,60,80,100,150$, and 360 minutes. Without disturbing the bed topography, the experiments were paused gently at the end of each test duration and the scour hole topography was mapped. The whole bed including the scour hole was then leveled at the end of each test duration after scour measurements and the new experiment is initiated with the flattened bed for the next mapping time. This procedure is repeated for the aforementioned test durations and experiments (E2-E7). For mapping of the bathymetry, SeaTek 5 MHz Ultrasonic Ranging System was used (SeaTek 2015). A frame was produced in the laboratory and 32 ultrasonic transducers of the equipment were placed in it. Attached to a wheeled tray on top of the flume, the frame was moved in transversal and longitudinal directions along the working section, and measurements were taken for mapping the erosion and accretion zones of the bathymetry around piers. The measurement accuracy of SeaTek Ultrasonic Ranging System is quite high. As also stated by Melville (2014) this accuracy is $\pm 1 \mathrm{~mm}$. Because of continuous alteration of the bed topographic conditions during the course of the experiments, gathering repeated scour depth measurements at a certain location at a specified time under the same conditions is not possible. Therefore, an uncertainty analysis for the time-dependent scour depth measurements was not conducted. In fact, apart from temporal evolution of scour depth measurements, carrying out an error analysis for different type of measurements, e.g. velocity and turbulence intensities would be relatively useful for having idea about the precision of the measurements. Studies conducted by Ataie-Ashtiani and Aslani-Kordkandi (2012, 2013) can be given as examples to such an analysis.

Considering the mapping times of the experiments E2-E7, 46 time-dependent threedimensional bed topography maps were created. The map of scour hole for run E2 at $t=360 \mathrm{~min}$ is presented in Fig. 2. Two-dimensional contour maps of all experiments can also be found in Selamoglu (2015). The shape of the scour hole has been observed to be almost time-invariant throughout the course of experiments. In addition, measured values of the scour depth at the upstream of the front pier are compared with a well-accepted clear-water scour equation presented 
by Melville and Chiew (1999) for single cylindrical piers and consistent scour depth development is obtained as presented in Selamoglu et al. (2014) and in Figure 3. Therefore, clear-water conditions were accepted to be maintained throughout the experiments. In the experimental range of this study (with minimum $\lambda=0.25$ ), combined scour holes are developed around the piers, leading to consistent results with Hannah (1978).

Scour hole volume $(V)$ needs to be determined to develop the semi-empirical model. The bed topographies obtained by the scour depth measurements are digitized to construct the scour hole bathymetry by a software, which is based on triangulation method. Using this method, discrete point data are converted into surface plots with bathymetry contours. With these digitized bathymetry maps, the unscoured bed level border is obtained for the scour hole volume calculations. Below the unscoured bed level border, the bulk volume of the scour hole was calculated by the software. Then, the net scour hole volume was calculated by subtracting the volume of piers below the unscoured bed level from the bulk volume. As a result, $V$ versus $t$ relation of the experiments was obtained. With a correlation coefficient $\left(R^{2}\right)$ of 0.92 , the regression equation of $V$ in SI system was obtained as:

$$
V=c_{1} t^{0.327} d_{s}
$$

where, $c_{l}=0.129 \lambda^{-0.387} b^{1.346}$ is a coefficient. In eq. (1), $t$ is in $\mathrm{s}, d_{s}$ is in $\mathrm{m}$ and $V$ is in $\mathrm{m}^{3}$. Equation (1) implies that time-dependent scour hole volume around dual piers with tandem arrangement is directly proportional to pier diameter, scour depth, and time while it is inversely proportional to $\lambda$ value. For clear water conditions, scour depth is directly proportional to flow intensity $\left(u / u_{c}\right)$ and flow depth $\left(d_{0}\right)$. Therefore, these effects are also considered implicitly in the scour hole volume expression. Considering fundamental similarity of scour holes under clear-water conditions, eq. (1) is assumed to be applicable to dual piers under different flow intensities and flow depths in the 
range of clear-water conditions. Therefore, eq. (1) was used to develop a semi-empirical model to determine the temporal variation of the scour depth around cylindrical piers in tandem arrangement.

For any combination of pier size and spacing, it was observed that the scour depth at the upstream of the front pier is the maximum scour depth inside the combined scour hole around tandem piers at any time. Reinforcing effect was clearly observed for the maximum test duration, for example for $b=7.5 \mathrm{~cm}$, approximately $7.5 \%$ increase in the maximum scour depth between piers was observed for $\lambda=0.33$ relative to the case when $\lambda=0.25$. Further details can be seen in Selamoglu (2015).

\subsection{Experiments on evolution of the scour depth}

The aim of this part of the experimental study was to obtain the evolution of the scour depth around the upstream pier with more frequent intervals. Different than the first part of the experiments, the ultrasonic distance measurement equipment was attached to the piers, such that it was possible to measure the scour depths continuously throughout the experiments. Four different frames (each holding eight transducers) were attached to piers, such as the front and side of the front pier, side of the rear pier and mid distance between the piers. As expected and also observed, the maximum scour depths were obtained at the upstream face of the front pier. Therefore, for design purposes, the concentration is focused on the temporal variation of this scour depth in the development of the model. Under the given conditions in Table 1, experiments were conducted and frequent measurements of scour depths were obtained as shown in Fig. 3. Knowing that scour depth evolves rapidly at the beginning of the experiments and gets slower towards the end, the scour depth measurements are recorded more frequently at the beginning. With reference to Table 1 and Fig. 3, for a particular flow intensity $\left(u / u_{c}\right)$ and pier spacing, the scour depth increases with increasing pier size. Also, for a particular pier size and spacing, the scour depth increases with increasing flow intensity. As mentioned earlier, the pier spacing affects the scour depth. In this 
study, $\lambda=0.50,0.33$, and 0.25 were used for $b=7.5 \mathrm{~cm}$ and $\lambda=0.33$ and 0.25 were used for $b=6.3 \mathrm{~cm}$ and $4.0 \mathrm{~cm}$. Similar to the results of the previous studies, the scour depths at front pier for $b=6.3 \mathrm{~cm}$ and $4.0 \mathrm{~cm}$ are higher when $\lambda=0.33$ compared to $\lambda=0.25$. In $b=7.5 \mathrm{~cm}$, highest scour depth at the front pier was observed when $\lambda=0.50$, and as expected it decreased with decreasing $\lambda$.

\section{Development of semi-empirical model}

A semi-empirical model was developed to determine the temporal variation of the spatial instantaneous maximum clear-water scour depth around dual cylindrical piers in tandem arrangement. The starting point of the model was the sediment continuity equation:

$$
\frac{d V}{d t}=Q_{s o}-Q_{s i}
$$

where, $Q_{s o}$ and $Q_{s i}$ are the volumetric rate of sediment transport carried out from and into the scour hole, respectively. For clear-water scour case there is no sediment transport from the upstream into the scour hole, therefore $Q_{s i}=0$. The variable $Q_{s o}$ can be formulated using a sediment pickup function (Yanmaz 2006):

$$
Q_{s o}=\beta \frac{E A_{p}}{\Delta \rho_{s}}
$$

where, $\beta$ is the coefficient of proportionality accounting for the geometry of the combined scour hole around dual piers and properties of sediment and flow, $E$ is the sediment pickup rate in mass per unit time and area, and $A_{p}$ is the unit area from which the sediment is picked up. Among several pickup functions reported in the literature, a proper one was selected with reference to the experimental conditions of this study. In fact, sediment pickup rate is assumed to represent the 
detachment of soil particles from the bed of the scour hole subject to horse-shoe vortex action. This function was proposed by Dey and Debnath (2001). This sediment pickup function, valid for horizontal, mild, steep, and adverse slopes with uniform and non-uniform sediments having sediment size range of $0.24-1.55 \mathrm{~mm}$ is as follows:

$$
E=0.0006 T D_{*}^{0.24} \sigma^{1.9} \rho_{s} \sqrt{\Delta g D_{50}}
$$

where $T=\left(\tau_{b}-\tau_{b c}\right) / \tau_{b c}$ is the transport-stage parameter due to scouring, $\tau_{b}$ is the bed shear stress on flat region of the scour hole, $\tau_{b c}=\psi \tau_{c r}$ is the critical bed shear stress on flat region of the scour hole, $\psi$ is a factor depending on turbulent fluctuations and oscillation of primary vortex, $\tau_{c r}$ is the critical bed shear stress on flat bed, $D_{*}=D_{50}\left(\Delta g / v^{2}\right)^{1 / 3}$ is the dimensionless particle diameter, and $v$ is the kinematic viscosity of water. For sloping beds, the term $T$ represents the mobility of sediment particles during pickup (Dey and Debnath 2001). The experiments are initiated with flat bed condition and as scouring process continues, steep slopes develop at the upstream and adverse slopes develop at the downstream of the piers. Therefore, use of eq. (4) is appropriate in a scour hole where horizontal, steep, and mild slopes exist. Pickup motion is modeled considering sediment, fluid, and flow properties, i.e. $D_{*}$ and $T$, which also includes the effect of turbulent fluctuations and oscillations of the horse-shoe vortices in the scour hole. This approach was applied satisfactorily to scour hole around abutments by Dey and Barbhuiya (2005), single piers by Yanmaz (2006), and abutments by Yanmaz and Kose (2009).

The temporal variation of $\tau_{b}$ was determined according to the bed shear stress model proposed by Kothyari et al. (1992). In this model, the bed shear stress at the pier nose is approximately $4 \tau_{0}$ before scour begins, where $\tau_{0}$ is the bed shear stress of the approach flow. As the cross-sectional area of the primary vortex increases during scouring, the bed shear stress decreases and when $\tau_{b}<\tau_{c r}$, equilibrium scour condition is reached. Similar to the assumptions made in previous studies 
(Yanmaz 2006; Yanmaz and Kose 2009), the time-averaged value of $\tau_{b}$ was assumed to be equal to the bed shear stress of the approach flow, $\tau_{0}$. During the scouring process, the corresponding $\psi$ term is not necessarily constant, but for computational ease an average value of $\psi$ may be used. In addition, equilibrium scour condition is reached when $\tau_{b}$ tends to $\psi \tau_{c r}$ (Dey and Barbhuiya 2005). Therefore, $\psi$ is a significant factor in scouring process and the average $\psi$ to be used in the computations should be determined carefully. In case of clear-water scour at abutments, $\psi=0.5$ was proposed by Barbhuiya (2003) and used by Dey and Barbhuiya (2005) and Yanmaz and Kose (2009). For clear-water scour at bridge piers, regarding the fundamental similarity of all clear-water scour hole characteristics, Yanmaz (2006) also used $\psi=0.5$. Dey (1996) stated that for clear-water scour at circular cylinders, $\tau_{b}$ tends to $0.3 \tau_{c r}$ based on the study of Melville and Raudkivi (1977) for bed shear stress at equilibrium. In the present study, a sensitivity analysis was carried out for $\psi$ term and the most suitable values producing good agreement of computed scour depths with experimental values were obtained for different experimental conditions, which will be discussed later.

The results of experiments on evolution of the spatial maximum scour depth were used to determine $\beta$; therefore $\beta$ was properly used to model the time-variation of this depth inside the combined scour hole, which occurs at the upstream face of the front pier. To determine the temporal variation of scour depth, eq. (2) was solved together with eqs. (1), (3), and (4). Then $\beta$ was determined as:

$$
\beta=\frac{\Delta \rho_{s}}{E A_{p}} \frac{d V}{d t}
$$

The unit area for sediment pickup for a single cylindrical pier scour was defined as the projected width of scour hole perpendicular to the flow at the upstream side of the front pier times the particle size (Yanmaz 2006). Although this pickup area definition was specifically given for a 
single pier case, it is still applicable in the present study since our ultimate goal is to determine the scour depth at the upstream face of the front pier. To calculate the projected width, side angles of the scour hole at the front pier was needed. From the bed topography maps of the experiments conducted in the first part of the study, side inclination of the scour holes were investigated. To this end, longitudinal scour hole width $(X)$, transversal scour hole width $(Y)$, and scour depth $(Z)$ at each test duration were obtained from the coordinates of the scour hole boundaries in front of and at the side of the front pier. Those characteristic widths and depth were also obtained at the end of experiments as $X_{\max }, Y_{\max }$, and $Z_{\max }$ (maximum characteristic lengths of the scour hole) at $t=360$ min. The correlations between $X / X_{\max }-Z / Z_{\max }$ and $Y / Y_{\max }-Z / Z_{\max }$ were determined and presented in Fig. 4 to investigate the rate of change of side inclination of the scour hole at longitudinal and transversal centerline axes of the front pier. From Fig. 4, it was observed that the shape of the scour hole at the front pier remains almost unchanged throughout the experiments and the side angles of the scour hole were almost equal to the angle of repose of sediment, $\phi$ except its rear face. Therefore, $A_{p}$ was calculated from $\left(2 d_{s} \cot \phi+b\right) D_{50}$. To solve eq. (5) derivative of $V$ was obtained as:

$$
\frac{d V}{d t}=c_{1} t^{0.327} \frac{d\left(d_{s}\right)}{d t}+0.327 c_{1} d_{s} t^{-0.673}
$$

Finally, inserting relevant parameters into eq. (5), $\beta$ was obtained as:

$$
\beta=\frac{\int c_{1} c_{2} t^{0.327} d\left(d_{s}\right)+\int 0.327 c_{1} c_{2} d_{s} t^{-0.673} d t}{\int\left(2 d_{s} \cot \phi+b\right) d t}
$$

in which, $c_{2}=\Delta \rho_{s} / E D_{50}$ is a coefficient. Using the experimental data of $d_{s}$ versus $t$ for the upstream face of the front pier aligned with the flow direction (shown in Fig. 3) for the limits of the 
integration, successive values of $\beta$ were computed from eq. (7). In the early stages of scouring, sediment transport rate from the scour hole is high resulting in large values of $\beta$, while the $\beta$ values decrease with time since $Q_{\text {so }}$ decreases. Therefore, to determine the temporal variation of the scour depth, $\beta$ term should be expressed in explicit form. Knowing that $\beta$ term accounts for the geometry of the combined scour hole, pier size, time, and properties of sediment and flow, various combinations of dimensionless parameters reflecting these characteristics were tested, such as $u_{*} t / b$, $u_{*} t / d_{0}, u_{*} t D_{50} / b^{2}, d_{s} /(b \tan \phi)$, and $u / u_{c}$. The functional forms of the considered combinations were:

$$
\beta_{1}=m\left(\frac{u_{*} t}{b}\right)^{x_{1}}\left(\frac{d_{s}}{b \tan \phi}\right)^{x_{2}}
$$

$$
\beta_{2}=m\left(\frac{u_{*} t}{d_{0}}\right)^{x_{1}}\left(\frac{d_{s}}{b \tan \phi}\right)^{x_{2}}
$$

$$
\beta_{3}=m\left(\frac{u_{*} t D_{50}}{b^{2}}\right)^{x_{1}}\left(\frac{d_{s}}{b \tan \phi}\right)^{x_{2}}
$$

$$
\beta_{4}=m\left(\frac{u_{*} t D_{50}}{b^{2}}\right)^{x_{1}}\left(\frac{d_{s}}{b \tan \phi}\right)^{x_{2}}\left(\frac{u}{u_{c}}\right)^{x_{3}}
$$

where, $m$ is a coefficient, $x_{1}, x_{2}$, and $x_{3}$ are exponents of the functional form of $\beta$. Coefficient and exponents of eqs. (8a) - (8d) were calculated by multiple linear regression analysis. Before selecting the representative $\beta$ combination to be used in all experiments, sensitivity analyses were carried out to select the best solution method to solve $\mathrm{d}\left(d_{s}\right) / \mathrm{d} t$ and $\psi$ value as mentioned earlier. The governing equation (eq. (9)) to be solved is a first-order nonlinear differential equation, which can 
be solved by a proper numerical method. Selecting $\psi=0.5$ as initial guess, $\beta_{1}$ combination was used to test some numerical solution methods, such as Euler, modified Euler, and $4^{\text {th }}$ order Runge-Kutta method. Using these methods, eqs. (2), (3), (6), and (8a) were solved together for $\mathrm{d}\left(d_{s}\right) / \mathrm{d} t$. The experimental $d_{s}$ - $t$ data of all experiments were compared with computed $d_{s}-t$ values using the aforementioned solution methods. Considering $R^{2}$ values and root mean square error (RMSE), modified Euler method was selected as the solution method to apply for all experiments to solve for $\mathrm{d}\left(d_{s}\right) / \mathrm{d} t$. After selecting the solution method, the optimum $\beta$ combination was selected again with $\psi=0.5$, considering average $R^{2}$ and RMSE values of the experiments. The representative $\beta$ combination to be used in the solution of $\mathrm{d}\left(d_{s}\right) / \mathrm{d} t$ was $\beta_{1}$ according to the selection criteria. Finally, $\psi$ values of the experiments were selected with similar criteria as above together with graphical comparison between experimental data and computed values of $d_{s}-t$. With regard to basic similarity of vortex fields in the scour hole, a common value of $\psi$ is desired to be obtained for a particular value of $\lambda$. Since volume of the scour hole depends on the $\lambda$ value, the experiments were grouped according to their $\lambda$ values. Therefore, $\psi=0.6$ was selected for $\lambda=0.50$ (E11 experiments) and $\psi=0.5$ was selected for both $\lambda=0.33$ and 0.25 (E12-17 experiments). $R^{2}$ and RMSE values of the solution method, $\beta$ combination, and $\psi$ trials can be found in Selamoglu (2015). Since $\beta$ was calibrated using the temporal variation of experimental scour depths at the upstream face of the front pier, the computed scour depths would also reflect the same location. Hence, solving for $\mathrm{d}\left(d_{s}\right) / \mathrm{d} t$ using the corresponding $\beta$ functions and other relevant parameters mentioned previously, the differential equations for different values of $\lambda$ are obtained as follows:

$$
\begin{aligned}
& \frac{d\left(d_{s}\right)}{d t}=1695\left(\frac{u_{*} t}{b}\right)^{-0.347}\left(\frac{d_{s}}{b \tan \phi}\right)^{-3.367} \frac{\left(2 d_{s} \cot \phi+b\right)}{c_{1} c_{2} t^{0.327}}-\frac{0.327 d_{s}}{t} \quad(\lambda=0.50) \\
& \frac{d\left(d_{s}\right)}{d t}=2603\left(\frac{u_{*} t}{b}\right)^{-0.595}\left(\frac{d_{s}}{b \tan \phi}\right)^{-1.465} \frac{\left(2 d_{s} \cot \phi+b\right)}{c_{1} c_{2} t^{0.327}}-\frac{0.327 d_{s}}{t} \quad(\lambda=0.33)
\end{aligned}
$$


(9c) $\quad \frac{d\left(d_{s}\right)}{d t}=2449\left(\frac{u_{*} t}{b}\right)^{-0.563}\left(\frac{d_{s}}{b \tan \phi}\right)^{-1.674} \frac{\left(2 d_{s} \cot \phi+b\right)}{c_{1} c_{2} t^{0.327}}-\frac{0.327 d_{s}}{t} \quad(\lambda=0.25)$

In Fig. 5, experimental and computed scour depths are compared for some of the experiments. The computed values of $d_{s}-t$ from eq. (9), in which $\Delta=1.65$ for quartz sand, are generally in good agreement with the experimental results. Therefore, dimensionless form of eq. (9) would be of practical interest. By substituting dimensionless time $T_{s}=t D_{50}\left(\Delta g D_{50}\right)^{0.5} / b^{2}$ and dimensionless scour depth, $S=d_{s} / b$ into eq. (9), the following dimensionless equations were obtained eventually as:

(10a)

$$
\frac{d S}{d T_{s}}=\frac{p(2 S \cot \phi+1)}{T_{s}^{0.674}(S \cot \phi)^{3.367}}-\frac{0.327 S}{T_{s}} \quad(\lambda=0.50)
$$

$$
\frac{d S}{d T_{s}}=\frac{p(2 S \cot \phi+1)}{T_{s}^{0.922}(S \cot \phi)^{1.465}}-\frac{0.327 S}{T_{s}} \quad(\lambda=0.33)
$$

$$
\frac{d S}{d T_{s}}=\frac{p(2 S \cot \phi+1)}{T_{s}^{0.890}(S \cot \phi)^{1.674}}-\frac{0.327 S}{T_{s}} \quad(\lambda=0.25)
$$

Here, $p$ is:

(11a) $\quad p=0.267 k^{-0.347} \frac{T D_{*}^{0.24} \sigma_{g}^{1.9}}{F^{0.347}} \quad(\lambda=0.50)$

$$
p=0.41 k^{-0.595} \frac{T D_{*}^{0.24} \sigma_{g}^{1.9}}{F^{0.595}} \quad(\lambda=0.33)
$$


(11c) $\quad p=0.386 k^{-0.563} \frac{T D_{*}^{0.24} \sigma_{g}^{1.9}}{F^{0.563}} \quad(\lambda=0.25)$

where, $p$ is a coefficient, $k=b / D_{50}$, and $F=u_{*} /\left(\Delta g D_{50}\right)^{0.5}$ is the square root of Shields' parameter. For a particular combination of flow, sediment properties, and pier size and spacing, $p$ is constant. Therefore, variation of $S$ with respect to $T_{S}$ is obtained by solving the nonlinear differential equation (eq. (10)) numerically. The solution of eq. (10) is presented in Fig. 6 as design charts to reduce computational efforts. The design charts presented here are for $\lambda=0.33$. For other values of $\lambda$, similar design charts are obtained and presented in Selamoglu (2015). The design chart implies that $p$ value increases with increasing flow intensity $\left(u / u_{c}\right)$ and decreasing $\lambda$ value. Prior to use of these charts, design inputs for pier, sediment, and flow characteristics are collected. Using the related information, the value of $p$ is computed for the selected $\lambda$ value. For a different value of $\lambda$ in the range $0.25 \leq \lambda \leq 0.50$, the value of $p$ can be computed by interpolation. Using the time to peak value of the design flood, dimensionless time parameter $T_{s}$ is computed. Therefore, with $T_{s}, p$, and $k$ values, the respective chart is used to determine the dimensionless scour depth and hence the scour depth is computed eventually.

\section{Conclusions}

A semi-empirical model was developed to predict the temporal variation of spatial instantaneous maximum clear-water scour depth at dual cylindrical uniform piers in tandem arrangement. The experiments were carried out with uniformly graded bed material having median size of $0.88 \mathrm{~mm}$. In the experiments, pier diameters of $7.5,6.3$, and $4.0 \mathrm{~cm}$ with pier diameter to spacing ratio of $0.50,0.33$, and 0.25 were used. The model was developed on the basis of sediment continuity approach and volumetric sediment transport rate out of the scour hole using a sediment pickup function proposed by Dey and Debnath (2001). Time-evolution of the volume of the scour hole around dual piers was obtained from the maps of the bed topography to be used in the model 
development. The results of the experiments showed that the shape of the scour hole at front pier remained almost constant in time. Design charts were derived giving the relation between dimensionless scour depth and time. Predicted scour depths were in relatively good agreement with the experimental results, in the test range. For the selected pier diameter to pier spacing ratios, it was observed that as the spacing between piers decreases, the scour depth decreases.

\section{References}

Ataie-Ashtiani, B., and Aslani-Kordkandi, A. (2012). Flow field around side-by-side piers with and without a scour hole. European Journal of Mechanics-B/Fluids, 36: 152-166.

Ataie-Ashtiani, B., and Aslani-Kordkandi, A. (2013). Flow field around single and tandem piers. Flow, Turbulence and Combustion, 90(3): 471-490.

Ataie-Ashtiani, B., and Beheshti, A.A. 2006. Experimental investigation of clear-water local scour at pile groups. Journal of Hydraulic Engineering, 132(10): 1100-1104. doi:10.1061/(ASCE)0733-9429(2006)132:10(1100).

Barbhuiya, A.K. 2003. Clear water scour at abutments. PhD thesis, Indian Institute of Technology, Kharagpur, India.

Basak, V., Baslamisli, Y., and Ergun, O. 1978. Local scour depths around circular crossectioned pier group. State Hydraulic Works Technical Bulletin, 28: 20-52 (in Turkish).

Beg, M. 2004. Mutual interference of bridge piers on local scour. In Proceedings of the Second International Conference on Scour and Erosion, Singapore. pp. 111-118.

Beg, M., and Beg, S. 2015. Scour hole characteristics of two unequal size bridge piers in tandem arrangement. ISH Journal of Hydraulic Engineering, 21(1): 85-96. doi:10.1080/09715010.2014.963176.

Breusers, H.N.C., Nicollet, G., and Shen, H.W. 1977. Local scour around cylindrical piers. Journal of Hydraulic Research, 15(3): 211-252. doi:10.1080/00221687709499645. 
Cardoso, A., and Bettess, R. 1999. Effects of time and channel geometry on scour at bridge abutments. Journal of Hydraulic Engineering, 125(4): 388-399. doi:10.1061/(ASCE)07339429(1999)125:4(388).

Chabert, J., and Engeldinger, P. 1956. Etude des affouillements autour des piles de ponts. Laboratoire National d'Hydraulique, Chatou, France (in French).

Chang, W.-Y., Lai, J.-S., and Yen, C.-L. 2004. Evolution of scour depth at circular bridge piers. Journal of Hydraulic Engineering, 130(9): 905-913. doi:10.1061/(ASCE)07339429(2004)130:9(905).

Coleman, S.E., Lauchlan, C.S., and Melville, B.W. 2003. Clear water scour development at bridge abutment. Journal of Hydraulic Research, 41(5): 521-531.

Dey, S. 1996. Sediment pick-up for evolving scour near circular cylinders. Applied Mathematical Modelling, 20(7): 534-539. doi:10.1016/0307-904X(95)00172-G.

Dey, S., and Barbhuiya, A.K. 2005. Time variation of scour at abutments. Journal of Hydraulic Engineering, 131(1): 11-23. doi:10.1061/(ASCE)0733-9429(2005)131:1(11).

Dey, S., Bose, S., and Sastry, G. 1995. Clear water scour at circular piers: A model. Journal of Hydraulic Engineering, 121(12): 869-876. doi:10.1061/(ASCE)0733-9429(1995)121:12(869).

Dey, S., and Debnath, K. 2001. Sediment pickup on streamwise sloping beds. Journal of Irrigation and Drainage Engineering, 127(1): 39-43.

Elliott, K.R., and Baker, C.J. 1985. Effect of pier spacing on scour around bridge piers. Journal of Hydraulic Engineering, 111(7): 1105-1109. doi:10.1061/(ASCE)07339429(1985)111:7(1105).

Ettema, R. 1980. Scour at bridge piers. Rep. No.216. Department of Civil Engineering, University of Auckland, Auckland, New Zealand. 
Fael, C.M.S., Simarro-Grande, G., Martín-Vide, J.P., and Cardoso, A.H. 2006. Local scour at vertical-wall abutments under clear-water flow conditions. Water Resources Research, 42(10): 388-399. doi:10.1029/2005WR004443.

Franzetti, S., Malavasi, S., and Piccinin, C. 1994. Sull'erosione alla base delle pile di ponte in acque chiare. In Proceedings of XXIV Convegno di Idraulica e Costruzioni Idrauliche, Vol. II, T4, Napoli, Italy. pp. 13-24 (in Italian).

Gao, P., Duan, M., Zhong, C., Yuan, Z., and Wang, J. 2013. Current induced scour around single piles and pile groups. In Proceedings of the Twenty-third International Offshore and Polar Engineering, Alaska, USA. pp. 472-477.

Garde, R.J., and Ranga Raju, K.G. 2006. Mechanics of sediment transport and alluvial stream problems, Third edition. New Age International Publishers, New Delhi, India.

Grimaldi, C., Gaudio, R., Cardoso, A.H., and Calomino, F. 2006. Local scouring at bridge piers and abutments: Time evolution and equilibrium. In Proceedings of the 3rd International Conference on Fluvial Hydraulics, Lisbon, Portugal. pp. 1657-1664.

Guo, J. 2014. Semi-analytical model for temporal clear-water scour at prototype piers. Journal of Hydraulic Research, 52(3): 366-374.

Hannah, C.R. 1978. Scour at pile groups. In Research Report No. 28-3. Civil Engineering Deptartment, University of Canterbury, Christchurch, New Zealand.

Heidarpour, M., Afzalimehr, H., and Izadinia, E. 2010. Reduction of local scour around bridge pier groups using collars. International Journal of Sediment Research, 25(4): 411-422. doi:10.1016/S1001-6279(11)60008-5.

Hoffmans, G., and Verheij, H.J. 1997. Scour manual. Balkema, Rotterdam, Netherlands.

Hosseini, R., and Amini, A. 2015. Scour depth estimation methods around pile groups. KSCE Journal of Civil Engineering, 19(7): 2144-2156. doi:10.1007/s12205-015-0594-7. 
Kim, H.S., Nabi, M., Kimura, I., and Shimizu, Y. 2014. Numerical investigation of local scour at two adjacent cylinders. Advances in Water Resources, 70: 131-147. doi:10.1016/j.advwatres.2014.04.018.

Kothyari, U., Garde, R., and Ranga Raju, K. 1992. Temporal variation of scour around circular bridge piers. Journal of Hydraulic Engineering, 118(8): 1091-1106. doi:10.1061/(ASCE)07339429(1992)118:8(1091).

Kothyari, U.C., and Kumar, A. 2012. Temporal variation of scour around circular compound piers. Journal of Hydraulic Engineering, 138(11): 945-957. doi:10.1080/09715010.2010.10515014.

Kothyari, U.C., and Ranga Raju, K.G. 2001. Scour around spur dikes and bridge abutments. Journal of Hydraulic Research, 39(4): 367-374. doi:10.1080/00221680109499841.

Lança, R., Fael, C., and Cardoso, A. 2010. Assessing equilibrium clear water scour around single cylindrical piers. In Proceedings of River Flow 2010, Braunschweig, Germany. pp. 12071213.

Link, O. 2006. Time scale of scour around a cylindrical pier in sand and gravel. In Proceedings of Third Chinese-German Joint Symposium on Coastal and Ocean Engineering, Tainan, Taiwan.

Lu, J.-Y., Shi, Z.-Z., Hong, J.-H., Lee, J.-J., and Raikar, R. V. 2011. Temporal variation of scour depth at nonuniform cylindrical piers. Journal of Hydraulic Engineering, 137(1): 45-56. doi:10.1061/(ASCE)HY.1943-7900.0000272.

Melville, B.W. 2014. Scour at various hydraulic structures: Sluice gates, submerged bridges and low weirs. Australian Journal of Water Resources, 18(2): 101-117.

Melville, B.W., and Chiew, Y. 1999. Time scale for local scour at bridge piers. Journal of Hydraulic Engineering, 125(1): 59-65. doi:10.1061/(ASCE)0733-9429(1999)125:1(59).

Melville, B.W., and Coleman, S.E. 2000. Bridge scour. Water Resources Publications, Highlands Ranch, Colorado, USA. 
Melville, B.W., and Raudkivi, A.J. 1977. Flow characteristics in local scour at bridge piers. Journal of Hydraulic Research, 15(4): 373-380. doi:10.1080/00221687709499641.

Mia, F., and Nago, H. 2003. Design method of time-dependent local scour at circular bridge pier. Journal of Hydraulic Engineering, 129(6): 420-427.

Oliveto, G., and Hager, W.H. 2002. Temporal evolution of clear-water pier and abutment scour. Journal of Hydraulic Engineering, 128(9): 811-820. doi:10.1061/(ASCE)07339429(2002)128:9(811).

Oliveto, G., and Hager, W.H. 2005. Further results to time-dependent local scour at bridge elements. Journal of Hydraulic Engineering, 131(2): 97-105. doi:10.1061/(ASCE)0733$9429(2005) 131$.

Salim, M., and Jones, J.S. 1998. Scour around exposed pile foundations. In Compilation of Conference Scour Papers (1991-1998), ASCE, Reston, VA.

SeaTek. 2015. SeaTek instrumentation and engineering. Available from http://seatek.members.atlantic.net/ [cited 4 May 2015].

Selamoglu, M. 2015. Modeling temporal variation of scouring at dual bridge piers. PhD thesis, Department of Civil Engineering, Orta Dogu Teknik Universitesi, Ankara, Turkey.

Selamoglu, M., Yanmaz, A.M., and Koken, M. 2014. Temporal variation of scouring topography around dual bridge piers. In Proceedings of the Seventh International Conference on Scour and Erosion, Perth, Western Australia. pp. 495-500.

Setia, B. 2008. Equilibrium scour depth time. In 3rd IASME/WSEAS International Conference on Water Resources, Hydraulics and Hydrology (WHH '08), University of Cambridge, UK. pp. $114-117$.

Sheppard, D., Melville, B., and Demir, H. 2014. Evaluation of existing equations for local scour at bridge piers. Journal of Hydraulic Engineering, 140(1): 14-23. doi:10.1061/(ASCE)HY.19437900.0000800 . 
Sheppard, D., Odeh, M., and Glasser, T. 2004. Large scale clear-water local pier scour experiments. Journal of Hydraulic Engineering, 130(10): 957-963. doi:10.1061/(ASCE)07339429(2004)130:10(957).

Simarro-Grande, G., and Martin-Vide, J.P. 2004. Exponential expression for time evolution in local scour. Journal of Hydraulic Research, 42(6): 663-665. doi:10.1080/00221686.2004.9628320.

Yanmaz, A.M. 2002. Bridge hydraulics. METU Press, Ankara, Turkey (in Turkish).

Yanmaz, A.M. 2006. Temporal variation of clear water scour at cylindrical bridge piers. Canadian Journal of Civil Engineering, 33(8): 1098-1102. doi:10.1139/106-054.

Yanmaz, A.M., and Altınbilek, H.D. 1991. Study of time dependent local scour around bridge piers. Journal of Hydraulic Engineering, 117(10): 1247-1268. doi:10.1061/(ASCE)07339429(1991)117:10(1247).

Yanmaz, A.M., and Kose, O. 2009. A semi-empirical model for clear-water scour evolution at bridge abutments. Journal of Hydraulic Research, 47(1): 110-118. doi:10.3826/jhr.2009.3222.

Zanke, U. 1978. Zusammenhange zwischen stromung und sedimenttransport. Mitteilungen des Franzius, Hannover, Germany (in German).

\section{List of symbols}

$A_{p} \quad$ unit area for sediment pickup

$b \quad$ pier diameter

$c_{1} c_{2}$ coefficient

$D_{50} \quad$ median sediment size

$D_{*}$ dimensionless particle diameter

$d$ center-to-center pier spacing

$d_{0}$ approach flow depth

$d_{s}$ scour depth 


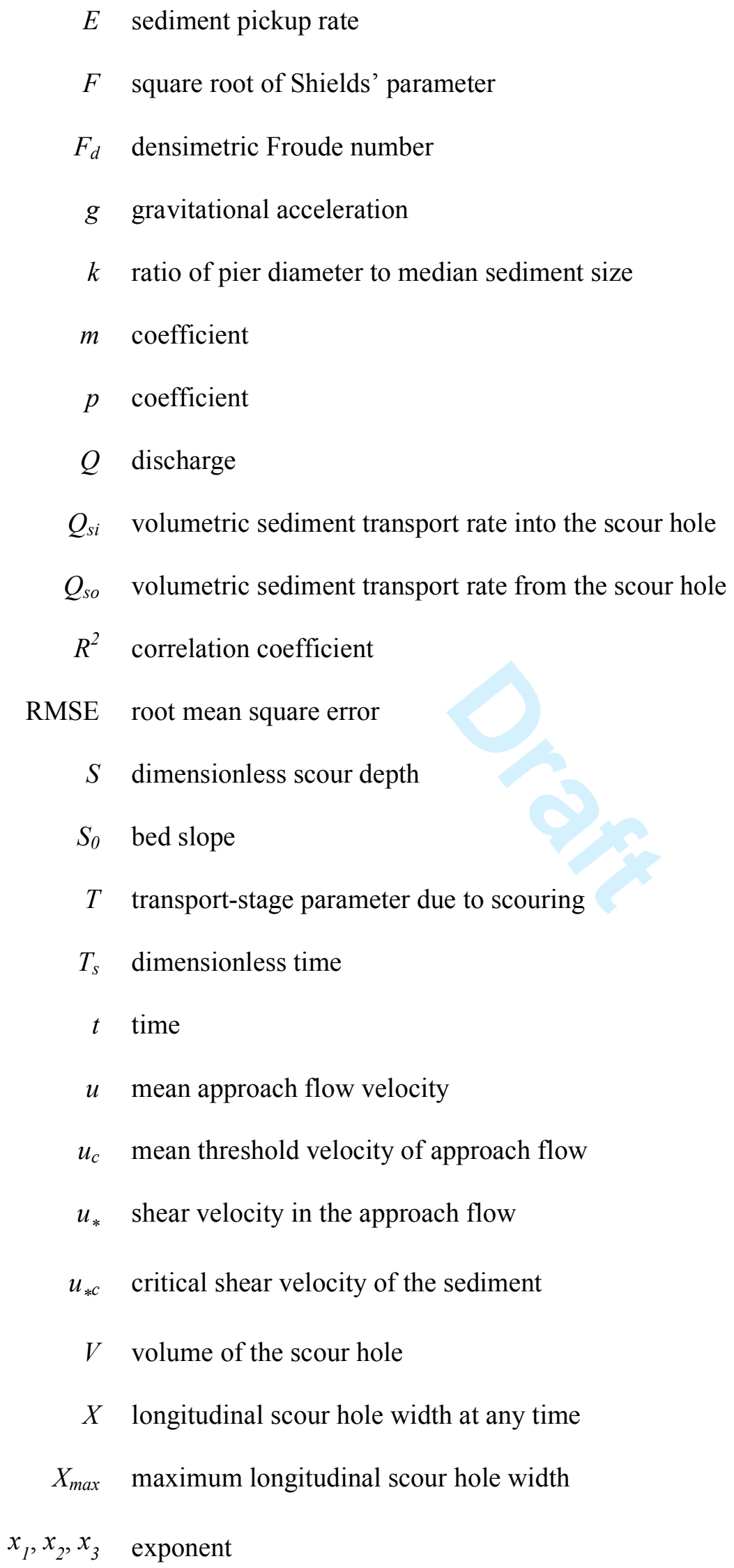


$Y$ transversal scour hole width at any time

$Y_{\max }$ maximum transversal scour hole width

$Z \quad$ scour depth at any time

$Z_{\max }$ maximum scour depth

$\beta \quad$ coefficient of proportionality

$\Delta$ relative submerged density

$\lambda$ pier diameter to pier spacing ratio

$v$ kinematic viscosity of water

$\phi \quad$ angle of repose of the sediment

$\rho \quad$ water density

$\rho_{s} \quad$ sediment density

$\sigma_{g} \quad$ geometric standard deviation of sediment size distribution

$\tau_{0} \quad$ bed shear stress of the approach flow

$\tau_{b} \quad$ bed shear stress on flat region of the scour hole

$\tau_{b c} \quad$ critical bed shear stress on flat region of the scour hole

$\tau_{c r} \quad$ critical bed shear stress on flat bed

$\psi \quad$ factor depending on turbulent fluctuations and oscillation of primary vortex 
Table 1. Experimental data.

\begin{tabular}{|c|c|c|c|c|c|c|c|}
\hline \multicolumn{8}{|c|}{ Part I } \\
\hline Run & $b(\mathrm{~cm})$ & $\lambda$ & $d_{0}(\mathrm{~cm})$ & $Q(\mathrm{lt} / \mathrm{s})$ & $u / u_{c}$ & $u_{*} / u_{* c}$ & $F_{d}$ \\
\hline E2 (11 runs) & 7.5 & 0.33 & 5.50 & 12 & 0.946 & 0.986 & 2.54 \\
\hline E3 (11 runs) & 7.5 & 0.25 & 5.50 & 12 & 0.946 & 0.986 & 2.54 \\
\hline E4 (6 runs) & 6.3 & 0.33 & 5.50 & 12 & 0.946 & 0.986 & 2.54 \\
\hline E5 (6 runs) & 6.3 & 0.25 & 5.50 & 12 & 0.946 & 0.986 & 2.54 \\
\hline E6 (6 runs) & 4.0 & 0.33 & 5.50 & 12 & 0.946 & 0.986 & 2.54 \\
\hline E7 (6 runs) & 4.0 & 0.25 & 5.50 & 12 & 0.946 & 0.986 & 2.54 \\
\hline \multicolumn{8}{|c|}{ Part II } \\
\hline Run & $b(\mathrm{~cm})$ & $\lambda$ & $d_{0}(\mathrm{~cm})$ & $Q(1 \mathrm{t} / \mathrm{s})$ & $u / u_{c}$ & $u_{*} / u_{* c}$ & $F_{d}$ \\
\hline E11-8 & $\overline{7.5}$ & 0.50 & 4.00 & 8 & 0.917 & 0.856 & 2.33 \\
\hline E11-10 & 7.5 & 0.50 & 4.75 & 10 & 0.936 & 0.924 & 2.45 \\
\hline E11-12 & 7.5 & 0.50 & 5.50 & 12 & 0.946 & 0.986 & 2.54 \\
\hline E12-8 & 7.5 & 0.33 & 4.00 & 8 & 0.917 & 0.856 & 2.33 \\
\hline E12-10 & 7.5 & 0.33 & 4.75 & 10 & 0.936 & 0.924 & 2.45 \\
\hline E12-12 & 7.5 & 0.33 & 5.50 & 12 & 0.946 & 0.986 & 2.54 \\
\hline E13-8 & 7.5 & 0.25 & 4.00 & 8 & 0.917 & 0.856 & 2.33 \\
\hline E13-10 & 7.5 & 0.25 & 4.75 & 10 & 0.936 & 0.924 & 2.45 \\
\hline E13-12 & 7.5 & 0.25 & 5.50 & 12 & 0.946 & 0.986 & 2.54 \\
\hline E14-8 & 6.3 & 0.33 & 4.00 & 8 & 0.917 & 0.856 & 2.33 \\
\hline E14-10 & 6.3 & 0.33 & 4.75 & 10 & 0.936 & 0.924 & 2.45 \\
\hline E14-12 & 6.3 & 0.33 & 5.50 & 12 & 0.946 & 0.986 & 2.54 \\
\hline E15-8 & 6.3 & 0.25 & 4.00 & 8 & 0.917 & 0.856 & 2.33 \\
\hline E15-10 & 6.3 & 0.25 & 4.75 & 10 & 0.936 & 0.924 & 2.45 \\
\hline E15-12 & 6.3 & 0.25 & 5.50 & 12 & 0.946 & 0.986 & 2.54 \\
\hline E16-8 & 4.0 & 0.33 & 4.00 & 8 & 0.917 & 0.856 & 2.33 \\
\hline E16-10 & 4.0 & 0.33 & 4.75 & 10 & 0.936 & 0.924 & 2.45 \\
\hline E16-12 & 4.0 & 0.33 & 5.50 & 12 & 0.946 & 0.986 & 2.54 \\
\hline E17-8 & 4.0 & 0.25 & 4.00 & 8 & 0.917 & 0.856 & 2.33 \\
\hline E17-10 & 4.0 & 0.25 & 4.75 & 10 & 0.936 & 0.924 & 2.45 \\
\hline E17-12 & 4.0 & 0.25 & 5.50 & 12 & 0.946 & 0.986 & 2.54 \\
\hline
\end{tabular}




\section{List of figure captions:}

Fig. 1. Plan view of the test flume (not to scale).

Fig. 2 Map of scour hole of run E2 at $360 \mathrm{~min}$.

Fig. 3. Experimental scour depths.

Fig. 4. Correlation between $X / X_{\max }-Z / Z_{\max }$ and $Y / Y_{\max }-Z / Z_{\max }$.

Fig. 5. Variation of $d_{s}$ with $t$.

Fig. 6. Design chart for $\lambda=0.33$. 


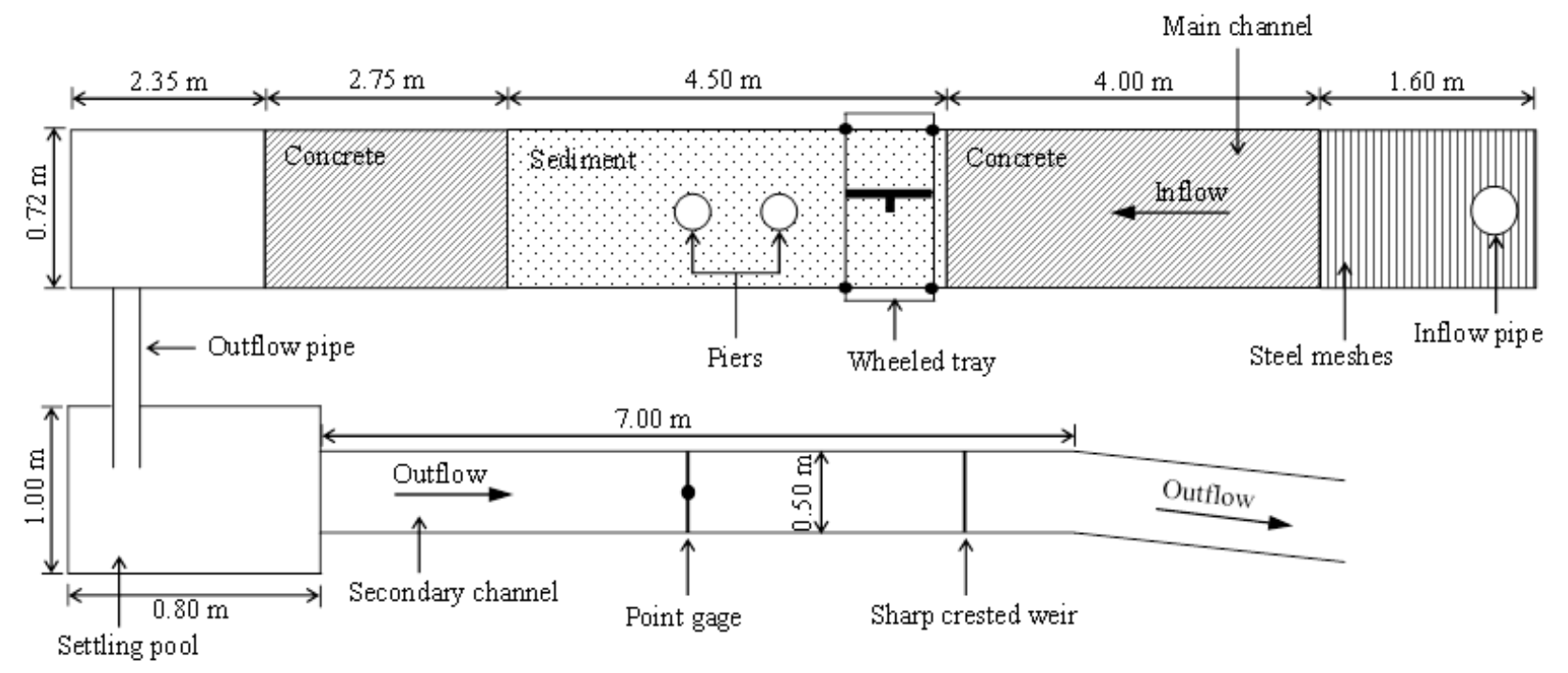




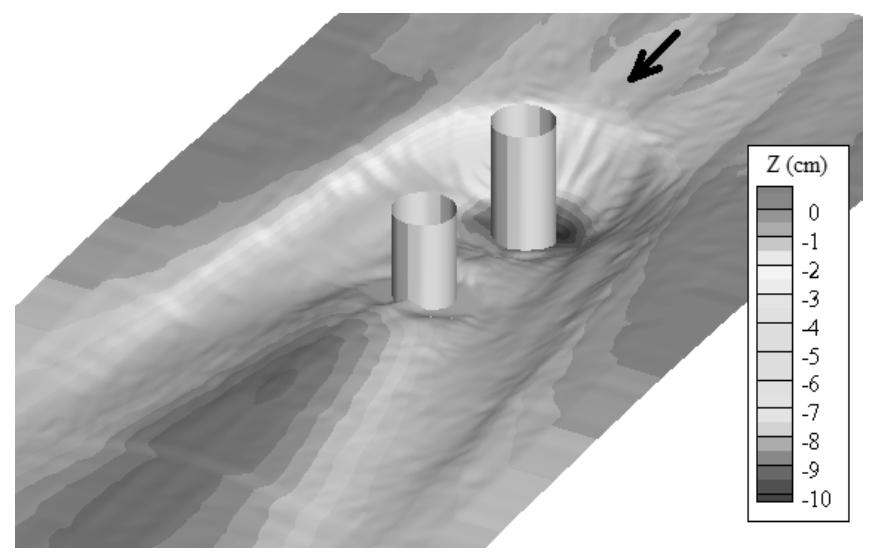

https://mc06.manuscriptcentral.com/cjce-pubs 


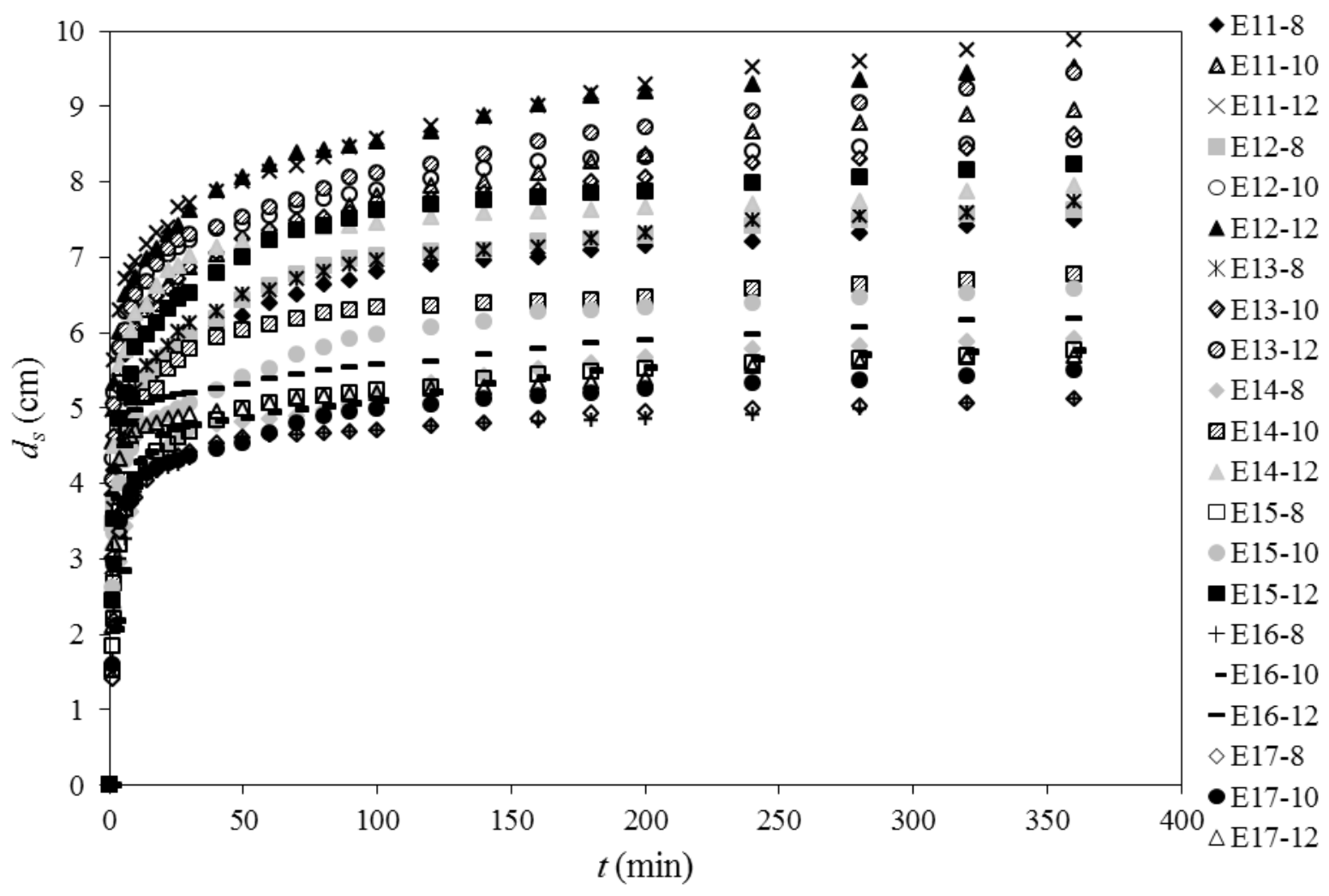



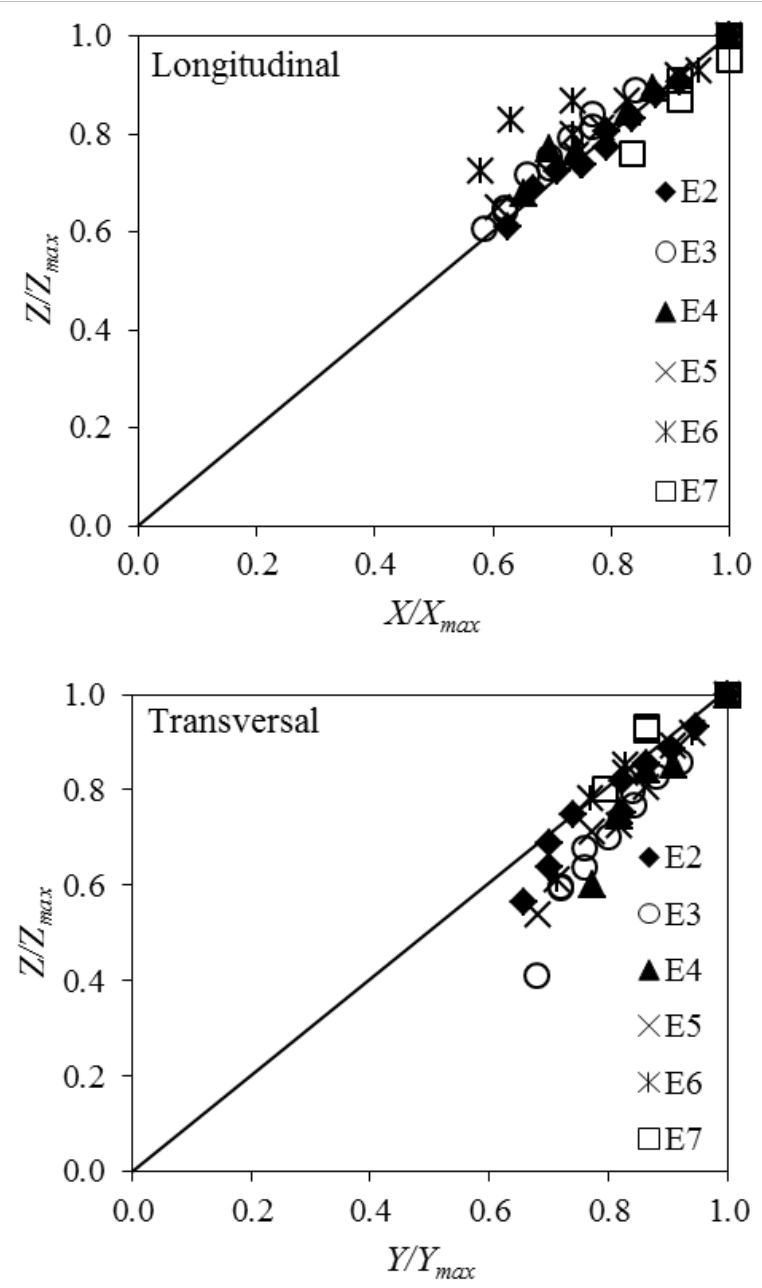

https://mc06.manuscriptcentral.com/cjce-pubs 

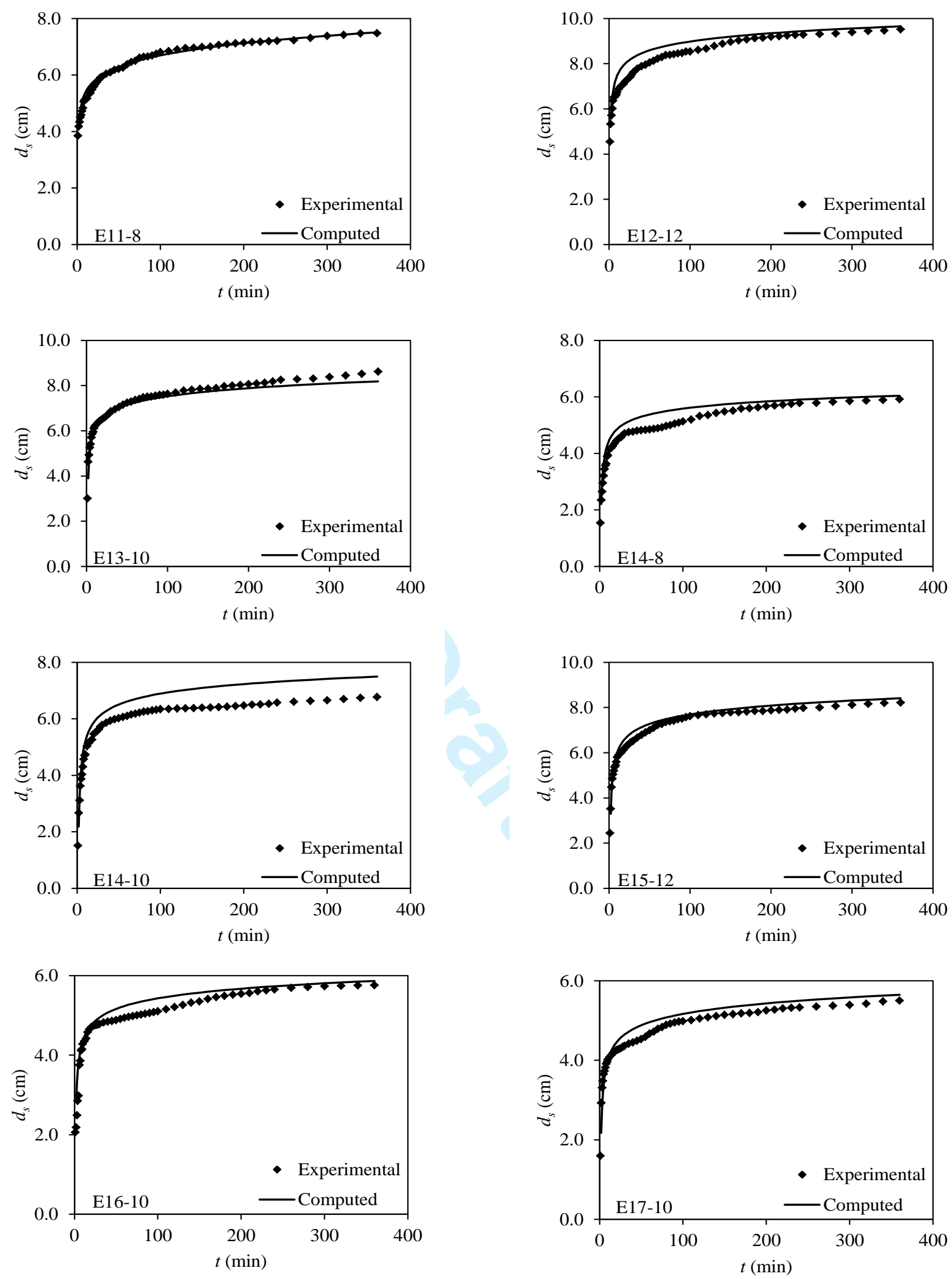

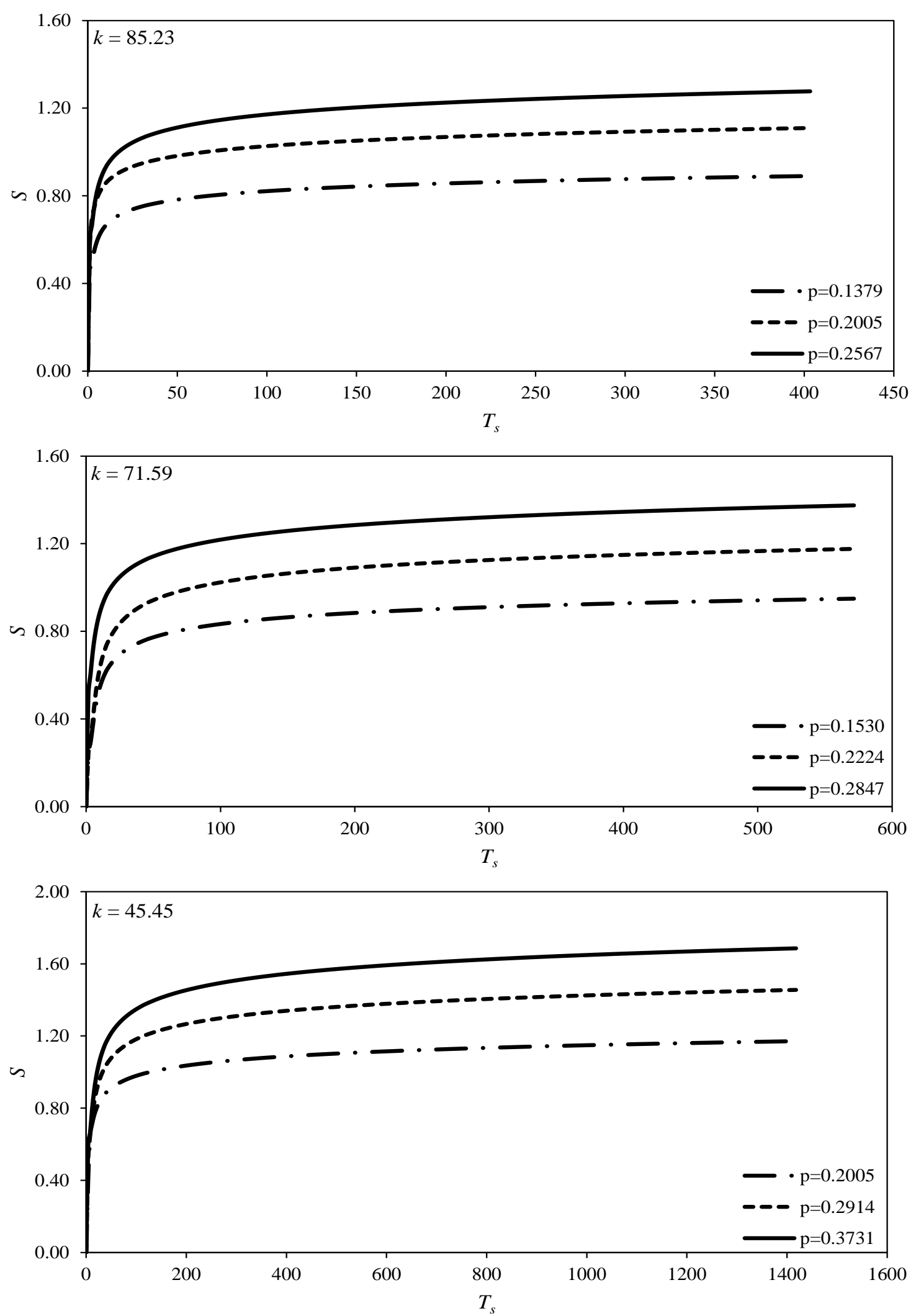